КРАЮШКИНА Татьяна Владимировна,

д-р филол. наук, главный научный сотрудник центра истории культуры и межкультурных коммуникаций Института истории, археологии и этнографии народов Дальнего Востока ДВО РАН (г. Владивосток).

Электронная почта: kvtbp@yandex.ru

\title{
Материальные ценности в пожеланиях Владивостокского новогоднего дерева желаний-2020 на русском языке: к вопросу об обществе потребления
}

\author{
УДК 394.262.5:159.9(571.63) DOI https://doi.org/10.24866/2542-1611/2021-3/36-48
}

иенности,

материальные

иенности,

современные иенности,

естественная

письменная речь,

новогодние пожелания,

психология россиян,

общество потребления
В статье на основе текстов Владивостокского новогоднего дерева желаний-2020 на русском языке исследуются материальные ценности. Вычленяется их перечень: деньги, жильё, автомобиль, техника и другие предметы вещного мира, путешествия, торжественные мероприятия. Делаются выводы о тенденции владеть необходимыми или престижными вещами, о значительной соотнесённости материальных ценностей со сферой индивидуального. Автор приходит к заключению, что не стоит современников категорично именовать обществом потребления, поскольку материальные ценности не являются доминирующими.

Исследование национальных ценностей является одним из приоритетных направлений гуманитарной науки. На уровне государства остро стоит вопрос о формировании перечня базовых национальных ценностей. Поэтому в науке назрела необходимость в изучении такого значимого аспекта на современном материале. Этим определяется актуальность данной статьи. Показательно, что работы исследователей, посвящённые духовным ценностям, количественно преобладают над работами, где затрагивается проблема ценностей материальных. Возможно, это связано с некоторой эмоциональной табуированностью темы.

Среди существующих определений ценности оптимальным представляется следующее: «Ценность всегда есть нечто положительное с позиции удовлетворения материальных, социальных или духовных потребностей человека <..>. <..> ценность <...> - это отношение человека к действительности, причём релевантное удовлетворению его положительных потребностей <..>» $[11$, с. 370].

Существует ряд классификаций ценностей. Ценности подразделяют на духовные, материальные и социальные [11, c. 370]; духовные, материальные и социально-политические (или общественно-политические, куда относятся свобода, братство, справедливость, равенство [1, с. 109]); материальные, духовные, социальные, личностные и организационные [5, с. 16], альтруизм, трансцендентные ценности, деятельностную активность, гедонистические ценности, самоактуализацию, межличностные отношения, материальные ценности, семью, ценности переживания, личностное благополучие [4, с. 11]. К синтетическим ценностям причисляют патриотизм, труд, обшение с людьми [1, с. 109]. 
А.М. Карп определяет материальные ценности следующим образом: «Материальные ценности призваны удовлетворять материальные потребности человека $<\ldots$. . Поэтому к материальным ценностям можно отнести $<\ldots .>$ : природные ресурсы и явления, жилище, одежду, орудия труда, материалы, технику, мебель, посуду, деньги и т.д. - то, что можно потрогать и можно приобрести за деньги» [5, с. 16].

И.В. Козов обнаруживает функциональную связь материальных ценностей с потребностями человека: они «необходимы для удовлетворения не только физиологических потребностей, но и потребностей в защищённости, удовольствии, доминировании, аффилиации, в обмене чувствами, познании, в социальном признании и самореализации» $[6$, с. 161$]$.

К исследованию материальных ценностей обращались представители ряда гуманитарных наук: лингвистики, истории литературы, истории религии, народной культуры. Материалом служили и диалектные фразеологизмы как трансляторы жизненных ценностей (Е.В. Брысина рассматривает богатство, пищу как материальные ценности казачества [2, с. 129]), и художественная литература (например, Р.Р. Шарипова изучала роль денег в жизни героев современного башкирского писателя Хайдара Тапакова [12]). Этнофестивали как явление современной народной культуры оценивались в качестве информационного пространства для «трансляции материальных и духовных ценностей народа» [9, с. 45].

B.М. Вивчар и М. М. Пеньков, сравнив системы духовных и материальных ценностей православия и атеизма, приходят к выводу об их кардинальном отличии [3]. А.Д. Космынина и А.В. Антончик, исследуя влияние буддизма на отношение к материальным ценностям, резюмируют: «В зависимости от существующих конфессии имеют место различные реакции на материальные блага: отрицание, смущение, стеснение, принятие в качестве дара свыше <...> [7, с. 155].

Материалом для данной статьи послужили тексты естественной письменной речи - пожеланий с Владивостокского новогоднего дерева желаний-2020. Пожелания представляют благодатный материал для выявления комплекса ценностей современных россиян. Если анкета подразумевает некоторый процент недостоверных сведений изза опасения огласки, то содержание новогодних пожеланий близко к абсолютной достоверности, поскольку они практически защищены от обнародования чувств и мыслей автора послания, идентификации с автором.

Всего среди 746 пожеланий на русском языке было обнаружено 233 текста с упоминанием материальных ценностей (это 31,23\% от общего числа). При этом некоторые из посланий содержат упоминание о нескольких материальных ценностях, поэтому речь будет идти не о 233, а о 276 упоминаниях материальных ценностей (при цитировании пожеланий орфография и пунктуация авторов сохранены).

Проанализированный материал лишь отчасти позволяет охарактеризовать адресатов и адресантов. Так, невозможным оказалось вычленить хотя бы минимальные данные адресатов в 118 пожеланиях, а в 122 - адресантов. Большая часть характеристик у авторов пожеланий и тех, кому они предназначены, совпадает, поскольку адресант и адресат зачастую являются одним и тем же лицом. Но есть и отличия. Суммарные данные по адресату и адресанту разнятся, поскольку в послании адресатом выступает не только сам адресант, но и другие люди. 
Итак, одной из характеристик адресантов является подпись, адресатов - упоминание их имени в пожеланиях. Было выявлено в пожеланиях 24 подписи адресантов и 29 упоминаний имени, имени и инициала фамилии, фамилии и инициалов имени и отчества. Это соответственно $10,76 \%$ и $13 \%$ от общего числа текстов. Только 2 подписи содержат указание на возраст, причём эти карточки заполнены взрослыми от лица маленьких детей (Ксю, 4 года; 4 года. Валерочка).

Большая часть имён позволяет обозначить пол адресантов. Среди адресантов, оставивших подписи, 9 лиц мужского пола (Попов Г.Г., Ваня, Вова Солодков), 11 - женского (чирЯ ялО, Бэлла, Даша П.). Была выявлена пара, состоящая из мужчины и женщины (Антон и Ульяна). Форма двух имён не дала возможности идентифицировать их гендерную принадлежность (Саша). Среди адресатов к 11 женским именам добавились ещё 3 имени, к 9 мужским - ещё 2, причём в одном пожелании именам сопутствует семейный статус (дочь Юля и сын Олег).

Большая часть характеристик адресантов и адресатов связана с семейным статусом. Среди адресантов и адресатов оказалось 9 незамужних женщин, 3 - замужних, 2 - не замужних и бездетных, 1 - замужем, без детей, у 4 - есть любимый мужчина. Три женщины идентифицированы через детей: 2 - матери дочери, не состоящие в отношениях, 1 - мать сына, не замужем, 2 - являются мужчинами, 1 пара, состоящая из мужчины и женщины. Но у большой части адресантов и адресатов, охарактеризованных через семью, невозможно вычленить пол. У 3 из них есть дети, у 1 - есть дочь, у 1 - есть сыновья, у 3 - есть сын, у 1 - есть сын (или внук), у 1 - есть ребёнок, 3 - не имеют детей. У 6 есть мать, у 1 - отец, у 1 - родители. У 28 круг родных неконкретен: 6 имеют родных, 14 - семью, 7 - близких, 1 - любимых.

12 адресантов не имеют удовлетворяющей их запросам работы, из этого числа только у одного адресанта был вычленен пол (женский). 2 мечтают о работе логопедом, 1 - мастером (речь идёт о сфере обслуживания), 1 - вести группу йоги, 1 - уйти в море. 1 является военнослужащей, 1 - портнихой, 1 - фотографом (мужчина), 1 - автовладельцем (или автовладелицей). Школьником (или школьницей) - 2, 1 - студентом (студенткой).

При этом наблюдаются и различия в составе адресантов и адресатов, обозначенных через семейный статус. К числу адресантов относятся 1 бабушка внучки, 1 - не состоящая в браке мать дочери и сына, 1 - женщина, имеющая мужа, сына, родителей, брата. У двух адресантов пол остался неясен, 1 из них имеет родителей и детей, а другой - дочь.

Список адресатов пополнился ещё 2-мя парами мужчины и женщины, 1 внучкой бабушки, 1 мужчиной, имеющим жену, дочь, сын, зятя, внука, 1 женщиной, имеющей мужа, дочь, сына, зятя, внука, 1 замужней матерью, у которой есть родители и брат, 1 женатым отцом, имеющим тёщу, тестя, шурина, 1 мужчиной, у которого есть родители, бабушка и дедушка, дядя. У трех адресатов пол определить невозможно, но у них есть отец или мать, мать и сестра, мать и брат.

Специфика пожелания с выражением потребности иметь чтолибо, существующего недостатка или страха перед появлением недостатка. Итак, о каких же материальных ценностях заявляется в проанализированных текстах? 
Самым популярным пожеланием, связанным с материальными ценностями, оказалась потребность в деньгах (всего 72 единицы). Идентифицировать авторов пожеланий этой группы удалось хотя бы отчасти в 16 текстах (22,22\%). Среди них превалируют женщины (9), в их числе 6 - не замужем, 1 - не имеет ребёнка, 1 - замужем и имеет детей, 1 - замужем, у нее есть ребёнок, родители и брат. Два адресанта подписались мужскими именами (Рома, Толя). 3 находятся в статусе детей, причём из контекста неясно, это несовершеннолетние или взрослые люди, имеющие родителей. Два автора находятся в статусе родителя (в пожеланиях упоминаются дети), но неочевиден пол адресантов. В двух пожеланиях были обнаружены подписи адресантов, не дающие какой-либо информации об авторах.

В ещё меньшем количестве пожеланий удалось хотя бы отчасти определить адресата (9 единиц, 12,5\%). Среди них 4 - муж / мужчина мечты, 3 - все, 1 - папа, 1 - моя семья. Очевидна традиционная для российского сознания привязка денег внутри семьи / отношений к мужчине: мужу, любовнику, отцу как главному добытчику.

Стоит обратить внимание на описание денег (оно встречается в 48 текстах). В большинстве случаев это упоминание денег (23), причём 18 - денег вообще, по одному пожеланию - денег в достатке и много денег, дважды - адресанты хотят бабла, единожды - финансов. Кроме того, упоминаются богатство (3), достаток (1), зарплата (3). Одно из пожеланий оформлено в виде рисунков, где изображены 2 купюры - в 100 и в 1000 единиц.

Встречаются в пожеланиях и упоминания конкретных сумм, как с указанием валюты, так и без. Чаще всего валюта не называется. Адресанты мечтают о 10 миллиардах (1), 1000000000 (1), миллиарде (2), миллионе (1), 1 миллионе (2), доходе в 1 млн в месяи, (1), зарплате в 100000 в месяи (2). Упоминаются только три вида валюты. Это доллары, рубли и некие деньги. Так Владивосток оправдывает свою удаленность от Европы: евро в пожеланиях не встретились. Адресанты хотят 10000000 \$ (1), 5 миллионов долларов (1), 1 миллион долларов (1). Ещё в двух случаях упоминается миллиард рублей и миллиард денег.

Значимой характеристикой денег является источник их получения. О нем заявляется в 28 текстах $(38,88 \%)$. Показательна противоположная цифра - в 44 текстах $(61,12 \%)$ источник дохода не озвучивается, видимо, причинами этого могут быть как особенность жанра пожелания кратко излагать мысли, так и инфантильность адресантов. Инфантильность проявляется и в том, что в значительном количестве пожеланий заявляется о потребности выиграть в лотерею (8) или просто выиграть (4). Среди лотерей упоминаются дважды «Столото» и единожды - «Русское лото» (Я хочу купить ios. И выиграть в столо$m o)$. К источникам дохода можно отнести других людей: мужа (5 единиц) или отца (1 единица). Если о материальном благополучии отца пишет ребёнок, то в случаях с пожеланием богатого мужа связана характерная для российского менталитета черта - перенос финансовой ответственности на мужа (Выйти замуж за хорошего состоятельного человека, здоровья родным, машину).

В 7 пожеланиях говорится о работе и заработке как источнике и средстве получения дохода, причём указывается желаемая зарплата (Хочу в 2020 год отличную работу с хорошей (100.000 рублей) зарплаmой). Существует и восприятие финансов, разделяющее доход и рабо- 
ту, нашло оно отражение и в проанализированных текстах (Здоровье, удача счастье, богатство! Замечательная работа логопедом).

О доходе в месяц заявляется в 1-м пожелании, туда относится, видимо, не только зарплата, но и другие источники дохода. Предположительно, речь идёт о финансово образованном адресанте (Здоровья маме, папе, сыну, мужу, брату. Мне успешного бизнеса, 15 клиентов каждый месяи. Доход 1 млн руб в месяи, путешествия (2 страны посетить). Построить дом. Купить новую машину. Доход в месяи, 1000000 руб. Счастья в тичной жизни, любви).

Показательны ещё два текста. Один из них по форме написания напоминает заговор с традиционным зааминиеванием, но для нас любопытно, что это практически единственный текст, где упоминается несколько источников дохода (Неиссякаемое богатство из различных источников АМИНЬ). Второе пожелание связано с возвращением собственных денег (Получить все мои деньги назад (долги)).

В текстах была вычленена цель получения денег. Сразу оговоримся, что желание купить те или иные предметы (о них будет идти речь ниже), не учитывалось; цель в данном случае связывается с закрытием разнообразных долгов и финансовой стабильностью. Цель получения денег прослеживается в 11 пожеланиях (3,98\%). Причём лишь в двух из них она напрямую связывается с получением денег. В первом случае это приобретение жилья (хочу чтоб нам в этом году, желательно до лета выплатили деньги на квартиру). А во втором - сугубо альтруистическая - деньги для всех (В этом году моя семья выиграла 1000000000 на благо мира!). Во-первых, цель связана с закрытием долгов (4; Чтобы мы закрыли все кредиты и улетели на Кубу и в Японию с (нечитаемо)), выплатить ипотеку (1), кредит (1), решить финансовые проблемы (1). Во-вторых, с получением финансовой стабильности (1), благополучия (1).

Опосредованно о получении денежных средств упоминается в ещё одном аспекте. Он связан с работой. Было выявлено 30 текстов, в которых работа называется как одна из значимых ценностей. Причём в 29 случаях говорится о потребности иметь работу и лишь в 1 - о желании работать. Чаще всего адресант говорит о собственной потребности в работе (28 текстов). Лишь в двух пожеланиях адресант сосредоточен на работе другого человека. В обоих случаях это близкая родственница - дочь или внучка. Значимо, что работа желается не в принципе, а оцениваемая высоко. (Ограниченный размер статьи не позволяет подробнее рассмотреть этот аспект.)

Ещё одна материальная ценность, обозначенная в пожеланиях, жильё (53 единицы). В 33 пожеланиях говорится о квартире, в 9 - $o$ доме, в 3 - о жилье, в 1 - о хате. При этом были выявлены пожелания, в которых вид жилья конкретно не обозначен. О том, что речь идёт о жилье, было ясно из контекста (3). А в ещё одном пожелании присутствует вариативность выбора: в нём говорится о покупке дома или квартиры.

Показательны характеристики жилья (11). В пяти пожеланиях адресант заявляет о желании новой квартиры. В двух случаях мечтают о трехкомнатной квартире. Один из адресантов имеет чёткое представление о жилье, где упоминается не только количество комнат, этажность, но и другие важные характеристики (Хочу квартиру 2 хкомн на 5 этаже в г. Владивостоке получить или купить в 2020 
году с лоджией в хорошем доме и районе). В одном из описаний жилья заявляется не только его качество, но и форма собственности ( $A$ я страстно желаю собственную благоустроенную приватизированную квартиру или дом! Здоровья своим родным и близким! Собственную полноценную семью с мужем и детьми! Отсутствие проблем! Да пусть это сбудется наконец-то!!! 06.01.2020). В двух пожеланиях используются сокращения, поэтому автор статьи интерпретирует их следующим образом: заявлено о желании иметь улучшенную (Я хочу Ул квартиру Г) или большую квартиру (Ребёнок, бол квартира).

Вычленяется в пожеланиях и такой аспект, как принадлежность жилья (14). Очевидно, что это жильё самого адресанта. В 7 текстах заявляется о своей квартире / своём доме, дважды - о собственном жилье и о жилье для себя. В трех других пожеланиях принадлежность жилья меняется. Она может как расширяться, включая адресанта и членов его семьи (Я хочу в 2020 году чтоб у нас с семьёей была квартира), так и сосредотачиваться на другом человеке (квартира умамы, y Егора).

В шести текстах обозначены населённые пункты, где адресант мечтает иметь жильё. Это Владивосток (3), Москва (2), Ялта (1). Из 51 текста, упоминающего о жилье, лишь в одном говорится о желании продать его. И в этом случае указан населенный пункт - один из городов Приморского края (В 2020 году продать квартиру от «Осталона» в Спасске).

Показателен и способ появления жилья. В 14 случаях заявляется о желании иметь квартиру (13 - хочy, 1 - желаю), при этом способ приобретения неважен. В 9-ти случаях говорится о приобретении жилья, причём 8-мь раз адресант заявляет о необходимости купить жильё (Купить новую квартиру (рисунок домика)), 1 раз - приобрести. В 2-х пожелания смещается акцент с актора: жильё должно появиться, каким образом - неважно.

В 11 текстах использованы односоставные конструкции (номинативные предложения). Им близки конструкции аффирмации, формулирующие желаемое как уже свершившееся. Таких текстов было выявлено 3, в них заявляется, что адресант и члены его семьи уже живут в доме или в своей квартире, упоминается и конкретная дата (В 2020 будет дом (рисунок двухэтажного дома с балконом) Вася). Это пожелание вызвало отклик у одной из читательниц пожеланий. Среди текстов мы нашли вот такой, который выглядит реакцией на предыдущее пожелание: Вася, позвони 2XXX-XXX ○.

Упоминаются и другие действия, связанные с жильём: в него планируют переехать (4), улучшить (1), получить или купить (1), продать (1), отремонтировать (2), достроить (1), построить (1). Ожидают, что на его покупку выплатят деньги (1).

Ещё одним популярным воплощением материальной ценности стало средство передвижения (в 18 пожеланиях). Несмотря на то, что Владивосток - город у моря, самым востребованным оказалось наземное транспортное средство (17 пожеланий) - автомобиль. (В 18-м пожелании адресант мечтает о вертолете (Милион долларов вертолет $u$ ПК)). При этом о покупке машины задумываются 2 мужчин, 6 женщин, а у 9 адресантов определить пол невозможно. Чаще всего его именуют машиной (11 пожеланий), в 4-х случаях называется конкрет- 
но разновидность автомобиля или его марка (джип; Ламборджини; Левин; chasen tourer V). Один раз автомобиль именуется тачкой, ещё один раз о нем говорится иносказательно (на больших колесах в лето). Упоминаются и характеристики автомобиля. Преобладает потребность в приобретении новой машины (4 единицы, причём 1 - о ней заявляет женщина, 3 - не удалось определить пол). О красивой машине мечтает одна адресантка, другая, видимо, уже заказавшая машину, переживает за её доставку (Получить свой Левин в иелости и сохранности!!).

Любопытны формулировки пожеланий. В одной группе сообщается о машине на уровне констатации (5 единиц) (Машина Ламборджини. Вадик). Во второй группе заявляется желание иметь автомобиль, используя глагол хочу (4 единицы) (Хочу машину Ваня ৩). В третьей группе упоминается покупка машины (6 единиц) (Купить новую а/машину). Ещё один текст сообщает о желании получить уже купленную машину целой. Размытыми оказались сроки приобретения автомобиля. Лишь в одном пожелании называется год покупки (B 2020 купить chasen tourerV).

В ряде текстов заявляется о желании обладать некими более мелкими предметами (техникой, одеждой, украшениями, игрушками; 51 текст) или животными (всего 7). Незначительная доля отведена пожеланиям, связанным с одеждой или аксессуарами (6). В одном случае речь идёт о потребности в красивой одежде вообще (Хочу жить во Владике. Хочу жильё. Хочу отпуск с мужем. Хочу красиво одеваться), а в двух других - о конкретном предмете одежде: костюме человекапаука или домашнем костюме в виде зверька - кигуруми. В текстах упоминается такой аксессуар, как рюкзак с четырьмя карманами.

В 2 текстах говорится об украшениях из драгоценного металла золота или белого золота. В первом случае адресантка изъявляет желание купить его сама, а во втором - получить предложение руки и сердца, при этом кольцо описано довольно точно (Хочу внимания, подарков, много совместно проведенного времени с любимым, хочу получить предложение с кольцом из белого золота с бриллиантом ОО).

В 26 текстах упоминается техника. Преобладает потребность получить те или иные предметы в собственное пользование. Только в 1 тексте говорится об оборудовании, связанном с медицинской сферой, для общего пользования (Анализатор имуннохимиополиниецентный mindraya2000 в поликлинику №1).

О какой же технике мечтают адресанты? Чаще всего - о смартфонах и телефонах. Преобладают тексты с конкретным описанием марок. Среди них известные всему миру iPhone Apple, xiaomi (11: айбонн 11про; айбон 11 про макс; айбон 11 promax; Appl Wanch 5 csr; XIAMI $A 5 ;$ телебон $Q 2 S$ и пр.). Упоминаются виды переговорных устройств (смартфоны, телефоны), операционные системы (Я хочу куnumь ios. $И$ выиграть в столото $\odot$ ). Но встречаются и тексты с упоминанием телефонов (5; Я хочу (;) себе телефон!; Новый телефон. Оля Стафеева).

В текстах обнаружены пожелания иметь компьютер (2), консоль для игры (2; PS4 Pro и PS4). По одному разу упоминаются планшет, планшет для рисования, наушники, квадрокоптер с крутой камерой, фотоаппарат, 3Dручка, итатив для телефона.

Игрушки, развивающие предметы, предметы быта, еда и напитки и прочее называются в 20 текстах. Стоит оговориться, что краткость 
формулировок не позволяет отделить игрушки от предметов, которыми пользуются взрослые (Барабан; нож кирамбит красный).

Среди детских материальных ценностей упоминаются куклы (Много L.O.L.; LOL; ночная и дневная Фурии; феечка Оливия; пупси слайм с домиком; черепашки ниндзя с трансформерами), машинки (машынка на пульти; мусоровоз; машинка), конструкторы (LEGO; лего ниндзя 204), настольные игры (арена бакуганов), печатные издания (книжка; манга), игрушечное оружие (бластер нёр б), мультипликационный фильм (Том и Джерри старый), волчки (много волчков), инструменты для рисования (большой набор маркеров chamellion). Дети всегда знают, чего хотят, чётко называют желаемый предмет. Только в одном тексте было выявлено неконкретное пожелание игрушек. Из сладкого упоминаются кока-кола (1) и конфетьл(2), причём конфет обязательно должно быть много. Выявлена и такая особенность детского менталитета: если упоминается количество, то это обязательно много: много конфет, много игрушек, много LOL. Как показывает анализ, желание материальных ценностей находится в рамках современного вещного мира. Но встретился 1 текст, выводящий за рамки предметных реалий нашего мира. Адресант высказывает желание иметь волшебную палочку.

В 8 текстах сообщается о потребности иметь животное, следует оговориться, что речь может идти и об игрушках. Чаще изъявляется желание иметь одно животное (6), реже - много (1) или двух (1). Предположительно, это всё детские желания, поскольку они сопровождаются детскими рисунками собаки, будки, кота, переноски для кота, мордочкой хомяка. Чаще всего адресант желает собаку (4), при этом только в одном тексте конкретизируется порода (Я хочу Померанского шпииа!!! Эля Алюреева). Ещё адресанты изъявляют желание иметь кота, хомяка, кролика, панду и дельфинов. Все тексты выстроены по модели я хочу + название животного. Только в одном тексте заявляется сила желания (Очень хочу собаку!!! ○), а в другом содержится обещание (Я хочу хомячка. Я буду за ним ухаживать (мордочка хомячка)).

Показатель современных ценностей - включение в список материальных ценностей временных или окончательных передвижений: путешествий, поездок, переездов. Потребность путешествовать преобладает над остальными видами передвижений. Самым популярным видом передвижения оказалось путешествие. О нём говорится в 28 текстах. Вырисовывается следующая классификация путешествий. В текстах может заявляться как об однократной поездке (21), так и о многократных (6), причём во втором случае конкретные места называются лишь в двух текстах (это Япония и Вьетнам; Куба и Япония), а преобладает неконкретное название: адресант мечтает о путешествиях вообще. В текстах с однократными путешествиями речь идёт о странах (Япония (2), Таиланд (1), Вьетнам (1)). Среди городов упоминаются по 1 разу Сеул, Токио, Прага, Рим, Венеиия, Москва (Я хочу себе поездку в Токио! От Евы С Новым годом!). Называется и остров - Бали (1) или район американского города (Голливуд). В одном из текстов не удалось расшифровать населенный пункт.

Значимо, как сами адресанты оценивают передвижение по миру. В этих текстах говорится о поездке (7), путешествии (7), желании в / на (5; Настоящих друзей рядом и в Тайланд), об отпуске (2; Хочу в отпуск 
загранииу всей семьей), о желании побывать (2), поехать отдыхать (1). И только в 3 случаях говорится о способе передвижения, это полет (Слетать туда куда хочешь).

В 26 текстах сообщается о собственном желании адресанта отправиться в путешествие, в 1 - оно связано с поездкой других людей (Ha работе чтоб любили. Хочу счастья здоровья себе, родителям детям. Никите и Алине счастья удачной поездки любви). Если в пожеланиях упоминается совместная поездка с другими людьми, то это самые близкие: семья (3), мама (1), муж (1). Встретилось и пожелание за подписью пары о совместном путешествии (Дорогой Дедушка Мороз! Mь очень хорошо вели себя в этом году. Подари нам, пожалуйста, билеть на Бали в январе 2020 ○ Антон и Ульяна). Среди пожеланий был выявлен только 1 текст, связанный с поездкой. В ней речь идёт о поездке ребёнка в детский лагерь (2К20 А Саныч в тагере!).

В 11 текстах заявляется желание поменять место жительства. Причём наблюдается следующая специфика: если речь идёт о территории России, то чаще упоминаются конкретные города: Иркутск, Москва, Санкт-Петербург, Сочи, хотя один раз сообщается о российском регионе (Хочу жить на юге России с тюбимым 31.12.2019 $($ Подпись)). В 5-ти случаях речь идёт о собственном желании адресанта. Любопытно, что одно из пожеланий вызвало ответный отклик у прочитавшего его человека. Первый текст гласит: Хочу переехать $в$ Питер!!! Ответ на него выглядит так: Мы с тобой. Поехали! В текстах называются два действия - переезд и жительство как его результат (Хочу жить в Сочи НГ 2022 в Сочи!!! Оля). Лишь в одном тексте осознаётся трудоемкость этого мероприятия (хочу чтобы у меня получилось приложить все усилия для переезда с Димой в Москву). В одном тексте город не называется, его единственная характеристика - другой (Финансовой стабильности. Переезд в другой город ()).

Переезд заграницу не имеет такой четкой локализации, как переезд в другие города России, он неконкретен. В текстах говорится о переезде в другую страну, заграницу (В 2020 желаю счастья и здоровья моим близким, а себе уехать загранииу. Хочу счастья своим детям!; Хочу переехать в другую страну. Пусть мечты сбываются (-)). Хотя называются и страны - Франция и Корея (Желаю, чтобы А и И жили вместе во Франиии ну или ещё где (подпись)). Из одного текста очевидно, что адресант живет какое-то время заграницей (Хочу остаться 8 Корее с мужем. (подпись)). Если в трех случаях говорится о собственном переезде адресанта заграницу, то в четвертом тексте переехать должны близкие адресанту люди.

К материальным ценностям могут быть отнесены и мероприятия, связанные с финансовыми затратами. В числе пожеланий нами были обнаружены три упоминания о свадьбах. (Для сравнения, о замужестве говорится в 29 текстах, т.е. результат для адресантов важнее торжественного мероприятия.) В первом тексте сообщается о собственной свадьбе с любимым человеком, адресантом выступает женщина (Свадьба с любимым Лёней Б.). Во втором тексте тоже, видимо, подразумевается собственный праздник (Свадьба 2020. (;))). В третьем тексте адресантом выступает мать или отец, речь идёт о свадьбе ребёнка (Хочу свадьбу дочери). Среди пожеланий оказалось и упоминание такого мероприятия, как концерт известного южнокорейского бойз-бэнда «ATEEZ» (Хочу на конщерт ATEEZ Г.П.). 
Подходя к завершению статьи, считаем необходимым обозначить ещё один значимый аспект: место материальных ценностей среди других типов ценностей. Последнее время в научной среде активно используется термин «общество потребления», которым называют наших современников. Е.Е. Самойличенко, А.В. Бунина, Е.Ю. Левчук отмечают: «Общество потребления характеризуется массовым потреблением материальных благ и формированием соответствующей системы ценностей и установок. Таким образом, ключевой идеей данного общества выступает максимальное удовлетворение материальных потребностей» [10, с. 14].

«...> потребительское общество сильно изменило нашу систему ценностей, которая является важнейшей характеристикой духовного мира человека, его мотивационной сферы и его индивидуальности. Очевидно, что личностная система ценностей всегда формируется, основываясь на ценностях, которые являются доминирующими в конкретном обществе, а они, в свою очередь, влияют на выбор индивидуальной цели каждого отдельного человека и на определение способов её достижения», - утверждает Н.В. Маслодудова [8 с. 10-108].

Ещё раз обратимся к анализу пожеланий, в которых упоминаются материальные ценности, и сосредоточим внимание на двух аспектах: очерёдности упоминания материальных ценностей в ряду других типов ценностей (тексты, в которых сообщается только о материальных ценностях, учтены не будут) и соседство - среди каких других типов ценностей упоминаются вынесенные в заголовок статьи.

Были выявлены перечни ценностей от двух до семи позиций. При анализе применялся упрощённый подсчет: учитывались первые места, последние места, середина, ближе к началу и ближе к концу. Итак, на 1-е место материальные ценности поставлены в 39 текстах, ближе к началу - в 20, посередине - в 15 , ближе к концу - в 24, на последнее место - в 49. Таким образом, в совокупности в начале и близко к началу стоят 59 упоминаний о материальных ценностях, а в конце и ближе к концу - в 73. Материальные ценности упоминаются в совокупности с другими типами в 93 текстах. Причём складываются как пары (например, материальная ценность и здоровье как ценность), так и большие по численности компонентов группы (куда относятся как ценности физиология (и здоровье в том числе), душевное состояние, социальная сфера, благополучие, достижение целей, стабильность и проявление жизненной позиции; новогодние пожелания показывают особый перечень ценностей).

В современной науке прослеживается тенденция делить ценности на черное и белое, где духовные ценности получают исключительно положительную оценку, а материальные - исключительно отрицательную. Духовное прошлое противопоставляется бездуховному, материальному настоящему. Столь безапелляционная оценка, кстати, являющаяся характерной чертой психологии человека на протяжении многих веков, никогда не шла на пользу истинному знанию. Подобные выводы в научном исследовании - результат поверхностного анализа.

При углублённом изучении этой темы становятся очевидны как негативные стороны некоторых духовных ценностей, так и позитивные - ряда материальных. Значимо, что в проанализированных текстах только $18,7 \%$ от общего числа пожеланий связаны лишь с материальными ценностями, ещё $12,46 \%$ - с материальными и другими, 
при этом почти 69\% пожеланий вообще не касаются материальных ценностей. Это и есть реальное отражение ситуации: нет оснований безапелляционно называть наших современников обществом потребления. Материальные ценности для россиян важны, но не доминируют в их сознании.

Итак, проанализированный материал позволил выявить очевидную тенденцию владеть престижными вещами, обладать большим количеством денег, чтобы никогда не нуждаться и приобретать всё желаемое. Но очевидно и другое - потребность иметь необходимое, в том числе жильё (причём речи об элитном жилье практически не идёт), интересную работу с достойным заработком. Формулировки ряда пожеланий позволили обнаружить и понимание соотношения запросов и возможностей.

Сравнивая исследованные нами ранее другие виды ценностей на данном материале, резюмируем о большей соотнесенности материальных ценностей со сферой индивидуального, с личными потребностями адресанта: чаще выражается его собственная потребность иметь те или иные предметы (существенно реже - его близких родственников). Мизерно (только два текста) количество пожеланий материальных ценностей для общего блага группы / всех людей. При исследовании пожеланий стала очевидна некая камерность материальных ценностей в восприятии современников: если духовные ценности значимы для всего человечества, то материальные - прежде всего для самого адресанта. С чем именно это связано - с жадностью, желанием престижа, дающего возможность доминировать над другими, пониманием несущественности материальных ценностей в рамках человечества или же с чем-либо ещё - предстоит выяснить в будущем. Но однозначного ответа в этом сложном вопросе не будет.

\section{Литература}

1. Белановская О.В. Жизненные планы и жизненные ценности у женщин возраста ранней и средней взрослости // Актуальные научные исследования в современном мире. 2017. № 10-3 (30). С. 108-113.

2. Брысина Е.В. Диалектный фразеологизм как отражение материальных и духовных ценностей казачества // Проблемы изучения живого русского слова на рубеже тысячелетий: мат-лы X Междунар. науч. конф. / науч. ред. А. Д. Черенкова. Воронеж: ВГПУ, 2019. С. 126-131.

3. Вивчар В. М., Пеньков М. М. Православие и атеизм: системы духовных и материальных ценностей (на материалах Каневского благочиния Ейской епархии) // Культура и время перемен. 2021. № 1 (32). URL: timekguki.esrae.ru/48-652 (дата обращения: 15.06.2021).

4. Волченков В.С. Ценности мужчин и женщин с разным уровнем и типом лич- ностной зрелости в ранней взрослости // Горизонты зрелости: сб. тез-ов уч-ков Пятой всерос. науч.-практ. конф. по психологии развития / под ред. Л.Ф. Обуховой, И.В. Шаповаленко, М.А. Одинцовой. М.: МГППУ, 2015. С. 10-13.

5. Карп А. М. Роль материальных и духовных ценностей во влиянии молодого лидера в коллективе // Проблемы социальной зрелости современной молодежи: матлы междунар. сем-ра мол. уч. и асп. / отв. ред. Н.А. Коваль. Тамбов: Тамбовская регион. общ. орг-ия «Общество содействия образованию и просвещению «Бизнес Наука - Общество», 2013. С. 16-20.

6. Козов И.В. Развитие материальных ценностей молодежи как психологического образования // Вестник Тамбовского университета. Серия: Гуманитарные науки. 2008. № 4 (60). С. 159-162.

7. Космынина А.Д., Антончик А.В. 
Влияние буддизма на отношение к материальным ценностям // Экономика и маркетинг в промышленности: мат-лы студ. науч.-техн. конф. / редкол.: А.В. Данильченко и др. Минск: БНТУ 2019. С. 154-155.

8. Маслодудова Н.В. Материальные блага в контексте смысложизненных ценностей современного потребительского общества // Научный компонент. 2019. № 3 (3). C. 104-109.

9. Пономарева В.Н. Событийное мероприятие как средство трансляции материальных и духовных ценностей народной культуры // Вестник науки и образования. 2019. № 6-2 (60). С. 45-48.

10. Самойличенко Е.Е., Бунина А.В., Левчук Е.Ю. Материальные и духовные ценности российской молодежи в условиях общественной нестабильности // Управление территориями и хозяйствующими субъектами в условиях экономической нестабильности: глобальные вызовы и механизмы развития: мат-лы науч.-практ. конф. Вологда: СЗИ, 2016. С. 12-19.

11. Сухина И.Г. Ценность как универсальный антропологический феномен: основы философского анализа // Российский гуманитарный журнал. 2015. Т. 4. № 5. C. 368-380.

12. Шарипова Р.P. Тема материальных и духовных ценностей в творчестве Хайдара Тапакова // Интеграция наук. 2016. № 2 (2).

C. $19-20$.

\section{Tatiana V. KRAYUSHKINA,}

Doctor of Philology, Chief Researcher of the Center for the History of Culture and Intercultural Communications of the Institute of History, Archeology and Ethnography of the Peoples of the Far East (Vladivostok, Russia). E-mail: kvtbp@yandex.ru

\section{Material Values in the WISHES of the Vladivostok New Year's Tree of Wishes-2020 in Russian: on the Question of the Consumersociety}

\section{UDC 394.262.5:159.9(571.63) DOI https://doi.org/10.24866/2542-1611/2021-3/36-48}

The article explores material values based on the texts of the values, Vladivostok New Year's Wish Tree-2020 in Russian. In part, material values, it is possible to find the data of the author and the addressee, modern values, namely, gender, age, marital status, and field of activity. The following list of material values is singled out: money, housing, car, equipment and other objects of the material world, travel, and festive events. A linguistic analysis of the description of psychology of Russians, material values is carried out, popular and unpopular positions consumer society are identified. Conclusions are made on the tendency to own necessary or prestigious things, about the significant correlation of material values with the sphere of personal consumption of the addressee himself, less often of his close relatives, scanty of a group of people. The author comes to the conclusion that there is no basis to categorically call contemporaries a consumer society, since material values are not dominant.

For citation: Krayushkina T. B. Material values in the wishes of the Vladivostok New Year's tree of wishes-2020 in Russian: on the question of the consumer society // Oriental Institute Journal. 2021. № 3. P. 36-48. DOI https:// doi.org/10.24866/2542-1611/2021-3/36-48 


\section{References}

1. Belanovskaya O.V. ZHiznennye plany i zhiznennye tsennosti $\mathrm{u}$ zhenshhin vozrasta rannej i srednej vzroslosti // Aktual'nye nauchnye issledovaniya $\mathrm{v}$ sovremennom mire. 2017. № 10-3 (30). S. 108-113.

2. Brysina E.V. Dialektnyj frazeologizm kak otrazhenie material'nykh i dukhovnykh tsennostej kazachestva // Problemy izucheniya zhivogo russkogo slova na rubezhe tysyacheletij: mat-ly X Mezhdunar. nauch. konf. / nauch. red. A. D. CHerenkova. Voronezh: VGPU, 2019. S. 126-131.

3. Vivchar V. M., Pen'kov M. M. Pravoslavie i ateizm: sistemy dukhovnykh i material'nykh tsennostej (na materialakh Kanevskogo blagochiniya Ejskoj eparkhii) // Kul'tura i vremya peremen. 2021. № 1 (32). URL: timekguki.esrae.ru/48-652 (data obrashheniya: 15.06.2021).

4. Volchenkov V.S. TSennosti muzhchin i zhenshhin $s$ raznym urovnem i tipom lichnostnoj zrelosti v rannej vzroslosti // Gorizonty zrelosti: sb. tez-ov uch-kov Pyatoj vseros. nauch.-prakt. konf. po psikhologii razvitiya / pod red. L.F. Obukhovoj, I.V. SHapovalenko, M.A. Odintsovoj. M.: MGPPU, 2015. S. 10-13.

5. Karp A. M. Rol' material'nykh i dukhovnykh tsennostej vo vliyanii molodogo lidera v kollektive // Problemy sotsial'noj zrelosti sovremennoj molodezhi: mat-ly mezhdunar. sem-ra mol. uch. i asp. / otv. red. N.A. Koval'. Tambov: Tambovskaya region. obshh. org-iya «Obshhestvo sodejstviya obrazovaniyu i prosveshheniyu «Biznes Nauka - Obshhestvo», 2013. S. 16-20.

6. Kozov I.V. Razvitie material'nykh tsennostej molodezhi kak psikhologicheskogo obrazovaniya // Vestnik Tambovskogo universiteta. Seriya: Gumanitarnye nauki. 2008. № 4 (60). S. 159-162.

7. Kosmynina A.D., Antonchik A.V. Vliyanie buddizma na otnoshenie $k$ material'nym tsennostyam // EHkonomika i marketing $\mathrm{v}$ promyshlennosti: mat-ly stud. nauch.-tekhn. konf. / redkol.: A.V. Danil'chenko i dr. Minsk: BNTU 2019. S. 154-155.

8. Maslodudova N.V. Material'nye blaga $\mathrm{v}$ kontekste smyslozhiznennykh tsennostej sovremennogo potrebitel'skogo obshhestva // Nauchnyj komponent. 2019. № 3 (3). S. 104109.

9. Ponomareva V.N. Sobytijnoe meropriyatie kak sredstvo translyatsii material'nykh i dukhovnykh tsennostej narodnoj kul'tury // Vestnik nauki i obrazovaniya. 2019. № 6-2 (60). S. 45-48.

10. Samojlichenko E.E., Bunina A.V., Levchuk E.YU. Material'nye i dukhovnye tsennosti rossijskoj molodezhi $\mathrm{v}$ usloviyakh obshhestvennoj nestabil'nosti // Upravlenie territoriyami i khozyajstvuyushhimi sub"ektami v usloviyakh ehkonomicheskoj nestabil'nosti: global'nye vyzovy i mekhanizmy razvitiya: mat-ly nauch.-prakt. konf. Vologda: SZI, 2016. S. 12-19.

11. Sukhina I.G. TSennost' kak universal'nyj antropologicheskij fenomen: osnovy filosofskogo analiza // Rossijskij gumanitarnyj zhurnal. 2015. T. 4. № 5. S. 368380 .

12. SHaripova R.R. Tema material'nykh i dukhovnykh tsennostej $\mathrm{v}$ tvorchestve KHajdara Tapakova // Integratsiya nauk. 2016. № 2 (2). S. 19-20. 